\title{
Land Acquisition Problems Project for Electrical Infrastructure Development
}

\author{
Adi Pitra Perdana ${ }^{1}$ and Mohammad Arif Rohman ${ }^{2}$ \\ ${ }^{1}$ Department of Management Technology, Institut Teknologi Sepuluh Nopember,Surabaya \\ ${ }^{2}$ Department of Civil Engineering, Institut Teknologi Sepuluh Nopember,Surabaya \\ e-mail:adipitraperdana@gmail.com
}

\begin{abstract}
The land is a critical resource for infrastructure development. However, land acquisition was still as the biggest problem in realizing infrastructure development in Indonesia. Electricity project is one of the infrastructure projects strategic and needs to be realizing in a short period. Effort at investigating the factors causing a problem in land acquisition for electricity infrastructure projects through an empirical method in Indonesia received scant attention. Therefore, the purpose of this study is to identify and critically assess the factors causing land acquisition problem for electricity infrastructure development using an empirical approach. The study adopted literature review and questionnaire survey. Literature review was using to identify the factors causing in land acquisition problem, which was using to design the questionnaire survey culminating in data analysis. In order to capture a broad perception, the questionnaires were administered to three different primary stakeholder groups comprised consultants, project owner and government. Data collected were analysed using mean score. The study revealed the mean score ranking of $\mathbf{2 4}$ identified factors causing in land acquisition problem for electrical infrastructure development. Five highest problems in land acquisition projects are (1) A project has not integrated with City Plan; (2) The part of land that is not acquired cannot be utilized by the owner; (3) Inventory data is not accurate; (4) Poor stakeholders coordination; (5) Differences interpretation of land acquisition regulations.
\end{abstract}

Keywords-Land Acquisitio, Infrastructure, Electricity.

\section{INTRODUCTION}

$\mathrm{L}$ AND acquisition is still the biggest problem in realizing $\downarrow$ infrastructure development in Indonesia. Infrastructure development that is be intensively carried out by the government is often constrained by protracted land acquisition problems. One of the acceleration of projects to be realized in a short period. Electricity infrastructure projects are accelerating to meet the national electricity program of 35,000 megawatts (MW). Infrastructure development is Carrie out in various regions in Indonesia, one of which is in East Java Province with the largest electricity demand projection in Indonesia and has an average increase of $5 \%$ per annum. The electricity infrastructure project that will be the biggest challenge is the construction of transmission infrastructure that requires land sites and through community lands.

The High Voltage Power Line and Extra High Voltage Power Line tower to support electricity transmission and distribution systems. Land area that is need for a voltage of $70 \mathrm{kV}$ to $500 \mathrm{kV}$ on average ranges from 225 square meters to 400 square meters. Since the enactment of Law Number 2 of 2012 concerning Land Acquisition for Development in the Public Interest, the mechanism for land acquisition has be regulated starting from the first stage of planning, preparation, implementation and delivery of results. However, in the context of efficiency and effectiveness, land acquisition for public interest which is not more than five hectares/small scale, can be carried out directly by agencies that require land with entitled parties as stipulate in Presidential Regulation Number 148 of 2015 concerning Amendments Fourth, Presidential Regulation Number 71 of 2012 the Implementation of Land Acquisition for Development in the Public Interest.

With the support of the acceleration of the project through the Regulation Regulations instrument in the small-scale land acquisition process, it has not yet had an effective impact on its realization. The risk of the execution of electricity infrastructure development can be hampering so that the realization deviates from the planned time target. The number of transmission infrastructure development targeted for COD (Commercial Operation Date) status in 2019 was 23 projects. However, of the 23 projects that has construction phase only 12 projects or $52 \%$. Obstacles to project completion are causing by several main causes including land acquisition problems. Land acquisition target is 15 hectares but only 8 hectares is realized or around $55 \%$. The ineffectiveness of the implementation of regulations for the release of transmission land and other internal and external constraints will have an impact on the incompatibility of project completion.

Several previous studies on land acquisition issues were see from various countries such investigating the causes of land acquisition delays for Public Private Partnership (PPP) projects in developing countries related to the issue of resettlement with political interference, not availability of replacement land with higher land transaction costs, weak planning and legality institutions.[1]. The problem of land acquisition in Ethiopia which states that the value of compensation is a major problem in land acquisition [2]. The issue of land acquisition in Ghana, which stated that in addition to the value of compensation there were administrative and political factors which were issues in the issue of land acquisition [3]. The problem of land acquisition especially on a small scale in electricity infrastructure projects in Indonesia has become a gap in this research.

From the background, it is necessary to know the significant factors that are the cause of problem in land acquisition projects. The research has implications for both policymakers considering land acquisition projects and stakeholders especially for electricity development, 
The $1^{\text {st }}$ International Conference on Business and Engineering Management (IConBEM 2020)

February $1^{\text {st }} 2020$, Institut Teknologi Sepuluh Nopember, Surabaya, Indonesia

Table 1.

Factor Causing Obstacles of Land Acquisition Project

\begin{tabular}{|c|c|c|c|c|}
\hline Code & Variable & Rank & Mean & $\begin{array}{l}\text { Standard } \\
\text { Deviaton }\end{array}$ \\
\hline F.3 & A project has not integrated with City Plan & 1 & 4.48 & 0.72 \\
\hline F.19 & The part of land that is not acquired cannot be utilized by the owner & 2 & 4.45 & 0.68 \\
\hline F.12 & Inventory data is not accurate & 3 & 4.41 & 0.83 \\
\hline F.10 & Poor stakeholders coordination & 4 & 4.36 & 0.73 \\
\hline F.1 & Differences in interpretation of land acquisition regulations & 5 & 4.20 & 0.68 \\
\hline F.8 & Non-physical losses are difficult to determine & 6 & 4.14 & 0.97 \\
\hline F.14 & The negotiation process is long & 7 & 4.13 & 0.73 \\
\hline F.4 & Different interpretations of land valuation standards & 8 & 4.12 & 0.78 \\
\hline F. 2 & Long consignment process & 9 & 4.03 & 0.87 \\
\hline F.17 & Delay of compensation / compensation & 10 & 4.03 & 0.66 \\
\hline F.18 & Changes in scope of work & 11 & 4.01 & 0.65 \\
\hline F. 5 & Property rights are difficult to identify & 12 & 3.94 & 0.75 \\
\hline F.7 & Land ownership conflict & 13 & 3.83 & 0.69 \\
\hline F.9 & Increase in land acquisition costs & 14 & 3.78 & 0.76 \\
\hline F.22 & Political resistance & 15 & 3.77 & 0.69 \\
\hline F.6 & Difficulties in the process of land transactions & 16 & 3.68 & 0.74 \\
\hline F.23 & Health impacts are not taken into account & 17 & 3.62 & 0.77 \\
\hline F.20 & Potential economic losses & 18 & 3.59 & 0.97 \\
\hline F.24 & Influence of community leaders & 19 & 3.52 & 0.78 \\
\hline F.16 & Incompetent staff & 20 & 3.48 & 0.78 \\
\hline F.11 & Landowners are less involved & 21 & 3.45 & 0.85 \\
\hline F.15 & Land acquisition selection process & 22 & 3.39 & 0.67 \\
\hline F.21 & Refusal to relocate & 23 & 3.28 & 0.76 \\
\hline F.13 & The process is not transparent & 24 & 3.00 & 0.89 \\
\hline
\end{tabular}

contribute to the realm of science that expand knowledge in project management, especially project land acquisition for development in the public interest.

\section{METHOD}

The data analysis method used in this research is descriptive statistics. Descriptive statistics are statistics used to analyse data by describing or describing data that has be collected as it is without intending to make conclusions that apply to the public or generalize [4]. Descriptive statistics in charge of describing a symptom with commonly used measures are the average value, standard deviation, variance, median and modus [5]. The variables used in this study are depicted in the Cartesian diagram mean-standard deviation to rank the factors that cause land acquisition problems in the electricity infrastructure project implemented by submitting a questionnaire to respondents who have been involved in this project. This analysis technique is common used for exploratory research [6].

The data analysis technique used is the analysis of the mean and standard deviation. The greater the mean value, the variable significantly influences. When analysing data obtained from a questionnaire survey using the mean, there are several factors that have identical scores, and to differentiate those factors in terms of ranking, standard deviation (SD) is calculated [1]. Standard deviation is a measure used to measure the amount of variation or spread of data value groups. Standard deviations close to 0 indicate that data points tend to be very close to the statistical mean (also called the expected value) of the set, while high standard deviations indicate that data points are scattered over great distances.

Respondents in this study are individuals who play a role in land acquisition projects for electricity infrastructure development, both as consultants, project owners and government. The questionnaire was filled in via the website with the total respondents who answered were 69 respondents who were grouped into three, namely consultants of 34 respondents (49\%), the project owner of 20 respondents (29\%) and government ( in this case the relevant institution is the National Land Agency) of 15 respondents (22\%). These three groups represent the main stakeholders in a land acquisition project.

\section{A. Validity and Data Reliability Test Results}

The quality of data collection is largely determining by the quality of the instruments or data collection tools used. A research instrument to be of good quality and can be justified if it has proven its validity and reliability. Testing the validity and reliability of the instrument, of course, must be adapted to the shape of the instrument that will be use in research. This study using SPSS software tools in testing the validity and reliability. The results of the data validity test using Pearson product moment, the $\mathrm{P}$ value is smaller than 0.05 (P value $<0.05$ ) for all variables. It can be concluding 
The $1^{\text {st }}$ International Conference on Business and Engineering Management (IConBEM 2020)

February $1^{\text {st }} 2020$, Institut Teknologi Sepuluh Nopember, Surabaya, Indonesia

that the data for this study are valid and further analysis can be continuing. The results of the data reliability test used Cronbach's alpha, then the Cronbach's Alpha value was 0.858 so that it was greater than 0.6 for all variables. It can be concluding that the data for this study are reliable and further analysis can proceed.

\section{RESULT AND DISCUSSION}

\section{A. Results of Analysis of Mean and Standard Deviation}

To get a ranking of the factors that cause significant obstacles to the land acquisition project for electricity infrastructure development, an analysis of the mean and standard deviation is carrie out. The results of the analysis of the mean and standard deviation obtained rank the variables according to the order of the most significant effect to the less significant. Five highest problems in land acquisition projects are (1) A project has not integrated with City Plan; (2) The part of land that is not acquired cannot be utilized by the owner; (3) Inventory data is not accurate; (4) Poor stakeholders coordination; (5) Differences interpretation of land acquisition regulations. Tables of mean and standard deviations are list in Table 1 . Factors causing obstacles of land acquisition project, on table 1.

A project has not integrated with City Plan is 4.48 as the mean value The problem of not integrating projects with city plan with small-scale land acquisition objects that have long stretch characteristics; coordination between several agencies that have different administrative areas is very much need. Different administrative regions have the potential to have policies or regulations that will be different. Therefore, at this stage the stakeholders cannot make assumptions that commonly occur and must be able to ensure the procurement object is in accordance with the provisions of spatial regulation in the administrative area. In the previous research, it has stated that basically, the effect of Urban and Regional Planning Decisions is to make the government responsible for planning at the national level. Likewise, local governments must be responsible for planning at the local level. [7];[8]. Lack of human and skilled human resources, as well as political interference, weaken the institutions of planning institutions. Land use regulations contribute to regulating the issue of compensation or compensation, in the study the researcher suggested that amendments to land use regulations could be consider a problem for land acquisition projects in Nigeria [9].

The owner is 4.45 as the mean value cannot utilize the part of land that has not acquired. There will be potential side effects due to the land being free too much to cut the land as a whole, so that the owner can no longer use the remaining land. This will be a conflict because the landowner is not willing to take part of the land only for the benefit of the project, but on the other hand, the project owner only needs a portion of the land to be acquiring for the sake of electricity infrastructure development. This was also mention in previous studies that the extent of the expanse or stretch that was release was a factor influencing the delay in land acquisition. [1].
Inventory Data is not Accurate is 4.41 as the mean value. According with Perpres No. 71 of 2012 concerning the Implementation of Land Acquisition for Development in the Public Interest, that for small scale land, inventory of procurement objects is carrie out by agencies that require land to be used as a basis for determining the right parties and as a basis for Public Appraisers / Land Appraisers to carry out valuation changes loss. The results of the inventory at least include the name, occupation, and address of the entitled party, the residence identification number or other personal identities of the entitled party, proof of ownership and / or ownership of the land, buildings, plants, and / or objects related to the land, land location, land area and area identification number, land status and documents, type of use and use of land, ownership and / or control of land, buildings, and / or other objects related to land, the imposition of land rights, and upper and underground spaces. Changes to the data made at the preparation stage even at the implementation stage will affect the valuation process for calculating fair replacement values. While inaccurate land inventory data will affect the difficulty of determining the form of physical losses and non-physical losses that have an impact on the disruption of the land acquisition process. Previous research that mentioned inaccurate data has been a barrier to the land acquisition process in public private partnership projects in Nigeria. [1].

Poor Stakeholders Coordination is 4.36 as the mean value. Stakeholders are individuals, groups or institutions that have an interest in the project, and who can influence the success of a project [10]. The importance of stakeholder's is involvement for project success factor [11]. Therefore, coordination between stakeholders as an identity formed with shared project goals, tolerance among stakeholders is an important factor in facing challenges to the success of a project. In its implementation, several stakeholders involved in land acquisition projects include the project owner, the government and an appraisal consultant. Each of these agencies will play a role in the process of land acquisition process with competencies that are own and will be interdependent. The characteristic of land acquisition for infrastructure with corridor type influences inter-agency involvement that can be distinguish from administrative areas. Then the coordination between agencies in regions that have different regulations will cause the potential to hinder the procurement process that has been previously plan. As in previous studies, poor interdepartmental coordination in the context of regional planning has been a component of obstacles to land acquisition projects in some developing countries that are not Commonwealth of Nations [1]. On the basis of development for the public interest, of course requires active participation from all parties, both from the regional government as an extension of government programs or projects, both regional and national scale so that good communication skills are required in order to provide an explanation and understanding how important the development is to the community. From this discussion, it can be conclude that poor coordination among stakeholders will be one of the main causes of obstacles in land 
The $1^{\text {st }}$ International Conference on Business and Engineering Management (IConBEM 2020)

February $1^{\text {st }} 2020$, Institut Teknologi Sepuluh Nopember, Surabaya, Indonesia

acquisition projects for electricity infrastructure development.

Differences interpretation of land acquisition regulations is 4.20 as the mean value. It cannot deny that developments activities in each country are closely relate to land acquisition as the location of development objects. In Indonesia, the system and purpose of land acquisition for the benefit of development projects is dividing into two, development in the public interest and development in the private interest. This division causes different mechanisms that are apply in the practice of land acquisition in the community [12]. Land acquisition for development that aims at public interest projects is regulated through separate regulations and mechanisms and involves the government as the executor, while in land acquisition for private interests, those who need land (private or non-private individuals) can do so through direct transaction channels such as well as buying and selling or exchange transactions. Ideally, a good law is a regulation that contains provisions that are uniquely and able to provide certainty and a clear picture of a term, especially at the lower level as a clarifying or implementing regulation of the above regulation, so that it does not lead to different interpretations - different. In reality, one of the problems of several laws and regulations regarding land acquisition in the public interest is the multi-interpretation of the notion of 'public interest'. Multi interpretation is one of the problems in the formal legal system in Indonesia related to land issues. The existence of multiple interpretations or multiple interpretations of the 'public interest' can be cause by the absence of a unification of the definition or understanding of the term 'public interest'. Legislation related to land acquisition for public purposes has different and changing definitions and meanings, which although their souls are not much different but have different equipment [13]. Furthermore, the other impact is that the community also carries out its own interpretation based on a minimum understanding of legal terms that may differ from government interpretations, for example there are community groups who understand the public interest as the interests of the group, and not the interests of the wider community [12]. In previous studies, there were two important problems that had to be resolved in land acquisition in the context of the public interest. First, because of ambiguity in land law in the context of research in Ethiopia, the concept of 'public use' has been interpreted in many ways for public purposes, public benefits, according to project needs and in accordance with the master plan. This broad interpretation of the term public use makes it difficult to understand what mean and when to take private land for public use. Second, there must be an appropriate mechanism to overcome this broad interpretation, either through legislative reform or through the process of land adjudication [14]. Therefore, different interpretations of land acquisition regulations are also a source of causes for obstacles in land acquisition projects.

\section{CONCLUSION}

The land acquisition process has been identifying as a complicated issue and the most challenging at the predevelopment phase of electricity infrastructure development. The study revealed the mean score ranking of 24 identified factors causing in land acquisition problem for electrical infrastructure development. Five highest problems in land acquisition projects are (1) A project has not integrated with City Plan; (2) The part of land that is not acquired cannot be utilized by the owner; (3) Inventory data is not accurate; (4) Poor stakeholders coordination; (5) Differences interpretation of land acquisition regulations. The research has implications for both policymakers considering land acquisition projects and stakeholders especially for electricity development, contribute to the realm of science that expand knowledge in project management, especially project land acquisition for development in the public interest.

\section{REFERENCES}

[1] S. O. Babatunde, O. Adeniyi, and O. A. Awodele, "Investigation into the causes of delay in land acquisition for PPP projects in developing countries,” J. Eng. Des. Technol., vol. 15, no. 4, pp. 552-570, 2017, doi: 10.1108/JEDT-05-2016-0029.

[2] A. G. Adam, "Thinking outside the box and introducing land readjustment against the conventional urban land acquisition and delivery method in ethiopia," Land use policy, vol. 81, no. November 2018, pp. 624-631, 2019, doi: 10.1016/j.landusepol.2018.11.028.

[3] A. Ahmed, E. D. Kuusaana, and A. Gasparatos, "The role of chiefs in large-scale land acquisitions for jatropha production in ghana: insights from agrarian political economy," Land use policy, vol. 75, no. August 2016, pp. 570-582, 2018, doi: 10.1016/j.landusepol.2018.04.033.

[4] Sugiyono, Metode Penelitian Kuantitatif dan Kualitatif dan R\&D. Bandung, 2010.

[5] H. Partino, HR, Idrus, Statistika Deskriptif. Yogyakarta: Safiria Insania Press, 2009.

[6] N. Fatimah, N. Wessiani, and Y. Rahmawati, "Analisis faktor-faktor keberhasilan penerapan budaya kaizen pada perusahaan manufaktur,' J. Sains dan Seni ITS, vol. 6, no. 1, pp. 47-49, 2017.

[7] A. Aribigbola, "Urban land use planning, policies and management in sub saharan african countries: empirical evidence from akure , nigeria,” Fourth Urban Res. Symp., p. 24, 2007.

[8] U. . Ikejiofor, "Planning within a context of informality: issues and trends in land delivery in enugu, nigeria," Case study Prep. Revisiting Urban Plan. Glob. Rep. Hum. Settlements, pp. 1-55, 2009.

[9] J. Ogedengbe, Brien, "Compulsory acquisition of oil exploration fields in delta state, nigeria,” J. Prop. Invest. Financ., vol. 25, 2015.

[10] G. Littau, P., Jujagirl, N., Jyothi, Adlbrecht, "25 years of stakeholder theory in project management literature (1984-2009),” Proj. Manag. $J$, vol. 41, no. 4, pp. 17-29, 2010.

[11] S. Rowlinson and Y. K. F. Cheung, "Stakeholder management through empowerment: modelling project success," Constr. Manag. Econ., vol. 26, no. 6, pp. 611-623, 2008, doi: 10.1080/01446190802071182.

[12] T. Suartina, “Analisa hukum pada kebijakan pembebasan tanah untuk kepentingan umum di indonesia,” J. Masy. Budaya, vol. 417, no. 1, 2018, doi: 10.1088/1757-899X/417/1/012032.

[13] I. G. A. B. Wiranata, "Reorientasi terhadap tanah sebagai objek investasi,” vol. 1, no. 1, 2007.

[14] M. Wubneh, "Policies and praxis of land acquisition, use, and development in ethiopia," Land use policy, vol. 73, no. February, pp. 170-183, 2018, doi: 10.1016/j.landusepol.2018.01.017. 